DOI : 10.5050/KSNVE.2010.20.2.153

$$
\begin{gathered}
\text { 공동 공진해석을 이용한 왕복동식 압축기의 } \\
\text { 기동소음 저감에 관한 연구 }
\end{gathered}
$$

\title{
Start-up Noise Reduction of Reciprocating Compressor Using Cavity Resonance Analysis
}

\author{
김 민 철*.김 원 진 \\ Min-Chul Kim and Won-Jin Kim \\ (2009년 11월 2일 접수 ; 2009년 12월 24일 심사완료)
}

Key Words : Reciprocating Compressor(왕복동식 압축기), Acoustic Analysis(음향해석), Start-up Noise(기동 소음)

\begin{abstract}
This work focuses on finding a method to reduce the noise of a hermetic reciprocating compressor during start-up using an acoustical analysis. The noise of compressor during start-up, which is a higher level than that of a normal operating condition, has transient and non-stationary characteristics. The acoustical analysis of compressor cavity is performed to find an effective method to reduce the noise level. In the acoustical analysis, the shape variations of frequency response function in the neighborhood of resonances are tested for three parameters: the height of remained oil, the suction position of refrigerant and the position of driving part. As a conclusion of this result, to reduce the emission noise of compressor during start-up, the height of remained oil should be kept at $16 \mathrm{~mm}$, the refrigerant should be sucked at the cross point of nodal lines of $\mathrm{X}$ and $\mathrm{Y}$ directional cavity modes, and the driving part should be positioned in the center of cavity.
\end{abstract}

\section{1. 서 론}

생활수준 향상으로 일반 가정에서 사용되는 가전 제품(home appliances)에 대한 저소음의 실현은 제 품 경쟁력을 결정하는 중요한 요소이며, 소비자들의 요구수준이 더욱 높아지고 있는 추세이다. 냉장고는 압축기, 열교환기, 송풍기의 고성능화 및 냉동 사이 클의 최적제어 등을 통한 에너지 저감, 쾌적성 향상 및 환경대응에 대한 기술발전이 비약적으로 이루어 지고 있다. 특히 쾌적함을 요구하는 현대에 기본적

† 교신저자; 정회원, 계명대학교 기계.자동차공학부

E-mail : wjkim@kmu.ac.kr

Tel : (053)580-5265, Fax : (053)580-5165

* 계명대학교 대학원 기계공학과
요건의 하나인 저소음화가 중요한 과제로 대두되어 소음관련 분야에 대한 연구가 활발히 이루어지고 있다. 일반 가정의 생활공간에 설치되는 냉장고는 지속적 또는 간헐적으로 운전되며, 이때 발생되는 소음이 비정상적이라고 인식될 때 제품에 대한 불 만족으로 나타나게 된다. 특히 냉장고의 단속운전 시에는 과도소음(transient noise)의 레벨이 높게 발 생되어 사용자 불만족의 원인이 되고 있다.

냉장고의 소음저감을 위해서는 주요 소음원인 압 축기(compressor)에 대한 소음저감이 중요하다 ${ }^{(1)}$. 소 형 압축기의 소음저감에 관한 연구로서, 압축기의 공 동 공진(cavity resonance)에 관련하여 기체 공간 공 명의 규명에 의한 밀폐형 압축기의 소음 저감에 관 한 연구 및 유한요소를 통한 밀폐형 압축기의 공동 
공진에 관한 연구 그리고 공동 공진과 진동 전달에 의한 소음저감에 관하여 흡입구 위치 변경과 루프 파이프 형상의 변경에 따른 소음저감에 관한 연구가 수행되었다 ${ }^{(2-5)}$. 압축기의 기동, 정지시 발생하는 진 동과 소음에 관련하여 구동부 지지스프링(spring)의 수명과 기동시 약 45초 동안 발생하는 $350 \sim 500 \mathrm{~Hz}$ 주파수대역의 기동소음을 $3 \mathrm{~dB}$ 줄이기 위한 연구를 수행하였으며, 목표 달성을 위해 일시적인 해결책과 조정으로 소음감소를 하였으나, 소음원에 대한 충분 한 고찰이 필요하다고 결론에 밝혔다 ${ }^{(6,7)}$.

이 연구에서는 음향해석을 통한 밀폐형 소형 왕 복동식 압축기가 기동할 때 약 20 초간 소음이 급격 히 상승하는 현상을 저감하기 위하여 잔존 오일 유 량, 냉매의 흡입위치 변경 그리고 구동부의 위치변 화에 따른 주요 공동 공진(cavity resonance)의 민 감도를 분석하고, 저소음형 압축기의 조건설정 및 설계방안을 제안하였다.

\section{2. 압축기의 모델링}

음향해석은 압축기의 내부 공동을 대상으로 하 였으며, 복잡한 내부 형상을 충분히 고려하여 모델 링하였다. 음향해석 상용코드는 $\mathrm{SYSNOISE}^{(8)}$ 를 사 용하였다. 소음해석에는 일반적으로 유한요소법 $(\mathrm{FEM})$ 과 경계요소법(BEM)이 사용되며, 여기서는 내부 음향문제해석에 적합한 유한요소법을 사용하 였다. Fig. 1은 공동의 형상모델과 유한요소 모델을 나타낸 것이다. 소음해석의 주파수 범위는 주요 공 동 공진주파수를 포함하는 영역인 $400 ~ 600 \mathrm{~Hz}$ 로 설정하였다. 음향해석에서 유한요소의 크기는 파장 $(\lambda)$ 의 $1 / 6$ 이하가 되어야 해석결과의 신뢰성을 가 진다. 식 (1)에서 $55{ }^{\circ} \mathrm{C}$ 일 때의 냉매(R134a) 내의 음속 $(c)$ 은 $169.7 \mathrm{~m} / \mathrm{s}$ 이고 주파수 $(f)$ 는 $600 \mathrm{~Hz}$ 이므 로 파장 $(\lambda)$ 의 길이는 $28 \mathrm{~cm}$ 가 된다. 따라서 압축 기 해석에 사용할 수 있는 최대 요소의 크기는 4.7 $\mathrm{cm}$ 이며, 이 해석에서는 $2.7 \mathrm{~cm}$ 의 요소 크기를 사 용하였다.

$$
\lambda=\frac{c}{f}
$$

여기서

$$
c \text { : Speed of sound }(\mathrm{m} / \mathrm{s})
$$

유한요소 모델에 사용된 요소는 사면체 요소(tetrahedral element)를 사용하였으며, 총 절점수(node number)는 3544 13,464개이며, 총 요소수(element number)는 14942 58157개이다. 압축기 음향해석에 서 사용한 냉매의 물성치는 Table 1 과 같다. Fig. 2 에 나타낸 바와 같이 잔존 오일 유량, 냉매의 흡입 위치, 그리고 구동부의 위치에 따른 압축기 내부의 음압에 대한 주파수응답 특성을 분석하기 위하여 운전조건 및 해석모델을 각각 다음과 같이 설정하 였다.

(a) 잔존오일의 변화

바닥면을 기준으로 유면을 $11 \sim 18 \mathrm{~mm}$ 범위에서 $1 \mathrm{~mm}$ 씩 변화시킨 8가지의 해석모델

(b) 냉매 흡입 위치의 변화

냉매 흡입관(suction pipe), 냉매 충전관(process

Table 1 Material properties

\begin{tabular}{c|c}
\hline \hline Density $\left(\mathrm{kg} / \mathrm{m}^{3}\right)$ & Sound speed $(\mathrm{m} / \mathrm{s})$ \\
\hline 1.206 & 169.7 \\
\hline
\end{tabular}

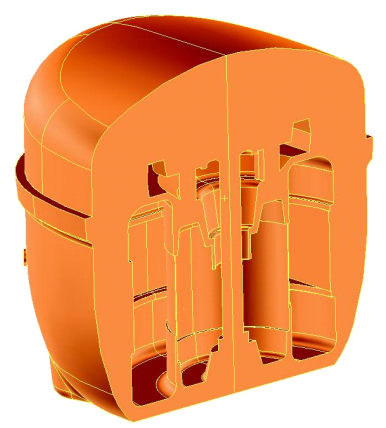

(a) Geometric model

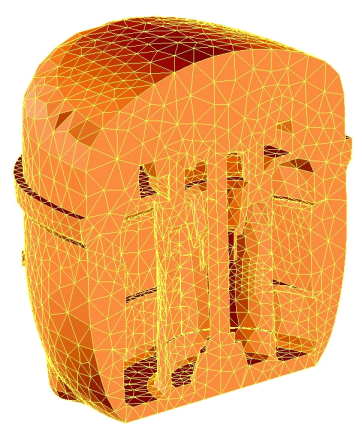

(b) Finite element model

Fig. 1 Compressor models 


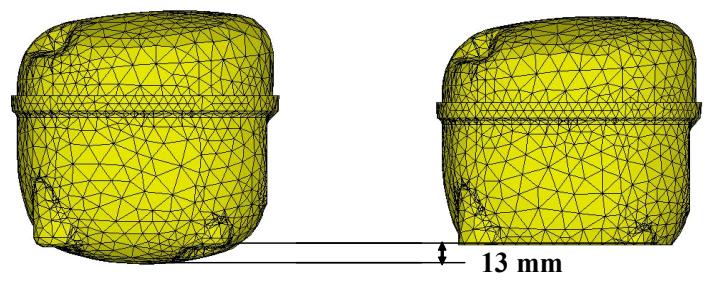

(a) Height of remained oil

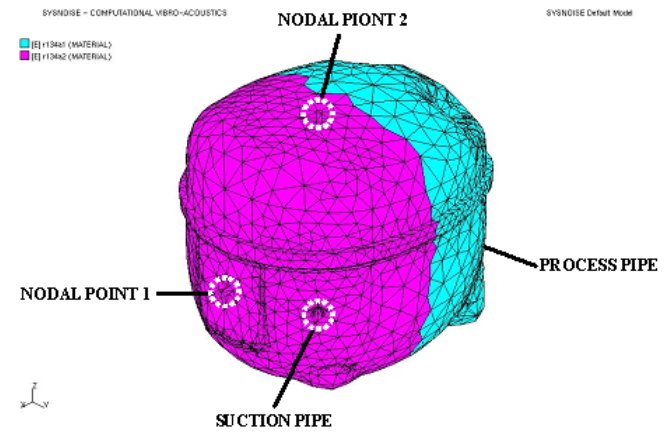

(b) Change of exciting positions

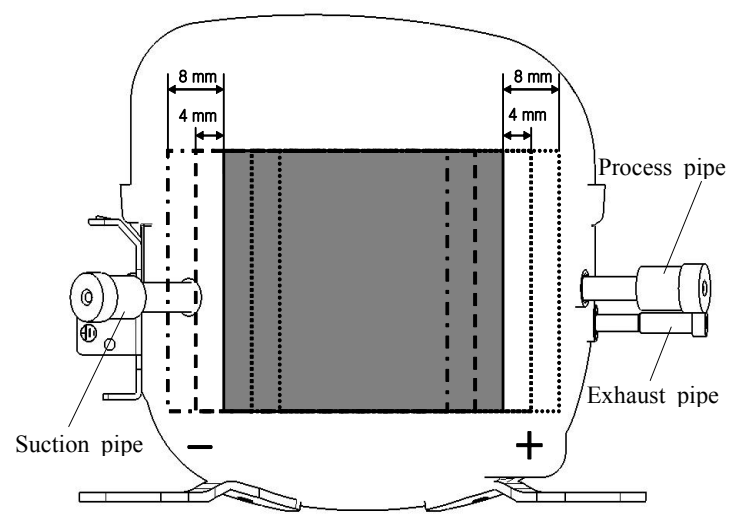

(c) Position of the internal driving part

Fig. 2 Finite element models for different analysis cases

pipe), 음향모드의 노달 라인(nodal line)상의 한 점으로 냉매의 흡입 위치를 변경한 4가지의 해석 모델

(c) 구동부 위치의 변화

구동부의 위치를 수평방향으로 각각 $\pm 4 \mathrm{~mm}, \pm 8$ $\mathrm{mm}$ 로 이동한 5 가지의 해석모델

\section{3. 음향 모드해석 및 해석모델의 검증}

압축기의 내부 공동에 대한 음향 모드해석을 수

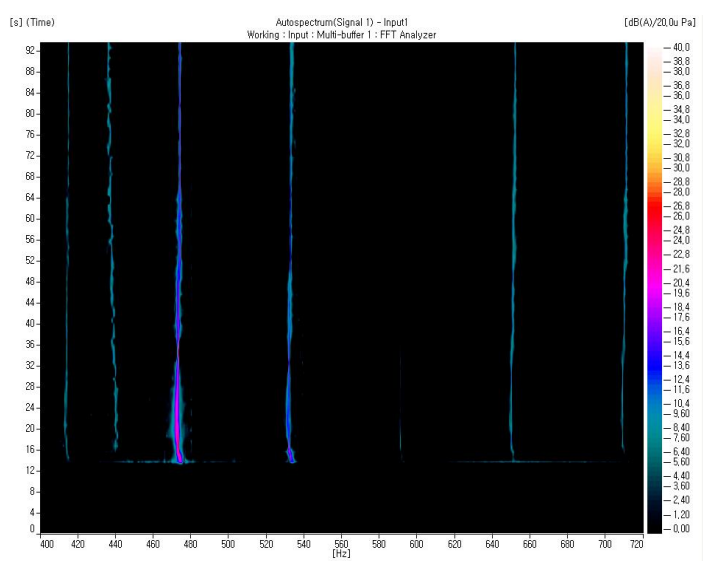

Fig. 3 Time scan analysis of noise spectrum

Table 2 Cavity resonance frequencies of compressor

\begin{tabular}{|c|c|c|c|c|c|}
\hline $\begin{array}{c}\text { Oil } \\
\text { height } \\
(\mathrm{mm})\end{array}$ & No. & $\begin{array}{l}\text { Frequency } \\
\quad(\mathrm{Hz})\end{array}$ & $\begin{array}{c}\text { Oil } \\
\text { height } \\
(\mathrm{mm})\end{array}$ & No. & $\begin{array}{c}\text { Frequency } \\
(\mathrm{Hz})\end{array}$ \\
\hline \multirow{3}{*}{11} & 1 & 449 & \multirow{3}{*}{15} & 1 & 441 \\
\hline & 2 & 467 & & 2 & 480 \\
\hline & 3 & 525 & & 3 & 521 \\
\hline \multirow{3}{*}{12} & 1 & 448 & \multirow{3}{*}{16} & 1 & 438 \\
\hline & 2 & 470 & & 2 & 487 \\
\hline & 3 & 524 & & 3 & 522 \\
\hline \multirow{3}{*}{13} & 1 & 446 & \multirow{3}{*}{17} & 1 & 436 \\
\hline & 2 & 473 & & 2 & 486 \\
\hline & 3 & 522 & & 3 & 521 \\
\hline \multirow{3}{*}{14} & 1 & 444 & \multirow{3}{*}{18} & 1 & 431 \\
\hline & 2 & 476 & & 2 & 487 \\
\hline & 3 & 521 & & 3 & 517 \\
\hline
\end{tabular}

행하고, 실험을 통하여 해석모델을 검증하였다. 실 험에 있어서 압축기의 기동소음은 약 20 초 동안 소 음레벨이 상승된 상태를 유지하다가 저감되는 과도 상태의 소음이므로 기존의 측정방법으로는 정밀한 분석이 어려웠다. 따라서 1 초 동안의 소음 주파수 스펙트럼을 100 초간 100 개를 측정하여 시간에 따른 주파수 스펙트럼의 변화추이를 3 차원으로 분석하였 다. Fig. 3은 온기동(warm start-up)조건에서 측정한 냉장고 후방의 소음 스펙트럼이다. 온기동 조건(냉 매온도 : $55{ }^{\circ} \mathrm{C}$ )에서 공동의 공진주파수는 446,474 , $533 \mathrm{~Hz}$ 임을 확인하였다. 실험과 같은 조건을 해석 모델에 적용하려면 기동 시에 비산되고 남은 오일 의 잔존 유량을 규명해야 한다. 잔존 유량의 변화는 

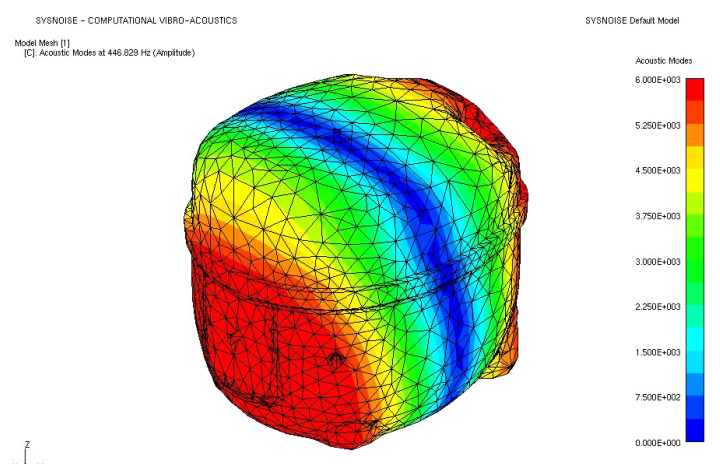

(a) $\operatorname{Side}(\mathrm{Y})$ direction $\operatorname{mode}(446 \mathrm{~Hz})$

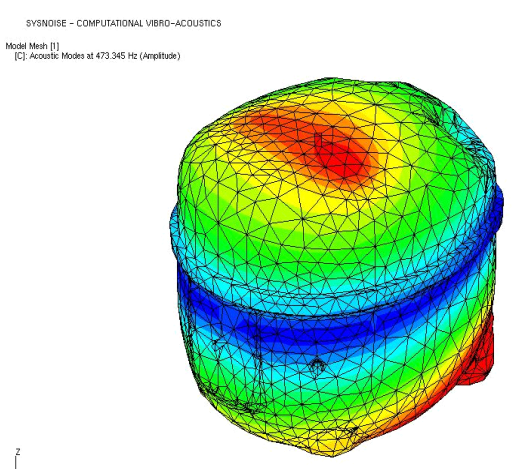

svenole Decturt trot

(b) Height(Z) direction mode $(473 \mathrm{~Hz})$

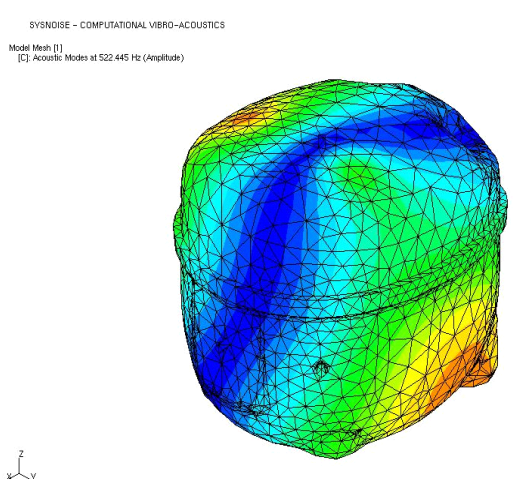

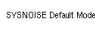

(c) front $(\mathrm{X})$ direction mode $(522 \mathrm{~Hz})$

Fig. 4 Acoustic modes of cavity

압축기 내부 공동의 부피를 변화시키는 중요한 변 수이다. 또한 압축기 윤활기구의 최저 높이가 압축 기 바닥면에서 약 $11 \mathrm{~mm}$ 에 위치하기 때문에 잔존 유량이 $11 \mathrm{~mm}$ 이하일 경우에는 오일이 순환되지 않는다. 따라서 바닥면에서부터 $11 \sim 18 \mathrm{~mm}$ 의 잔존 유량 높이를 각각 $1 \mathrm{~mm}$ 간격으로 모델링하여 해석 한 결과와 실험결과를 비교하여 가장 일치하는 압

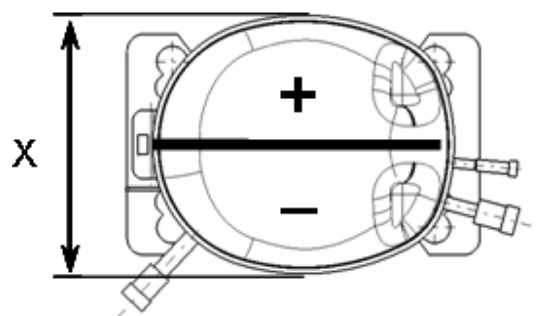

(a) X-direction mode

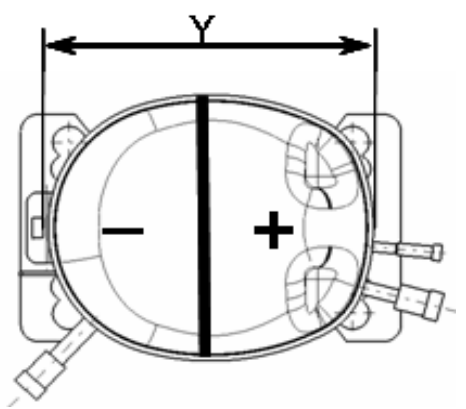

(b) Y-direction mode

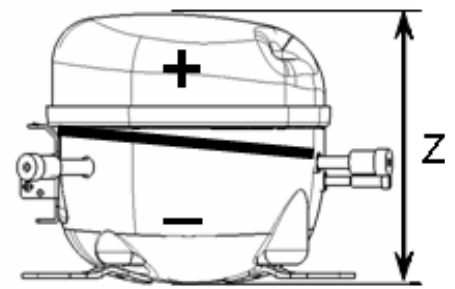

(c) Z-direction mode

Fig. 5 Directivity of cavity mode

\section{축기 모델을 도출하였다.}

잔존 유량의 변화량에 따른 공동 내부의 공진주 파수는 Table 2에 정리하였으며, 음향모드는 Fig. 4 와 같다. 잔존 유량이 증가하면 압축기 내부 공동의 부피는 감소한다. 압축기가 기동하기 전의 유량은 $18 \mathrm{~mm}$ 이며, 이 조건에서 공동의 주요 모드는 431, $487,517 \mathrm{~Hz}$ 이다. 여기서 $431,517 \mathrm{~Hz}$ 의 공진주파 수는 기동 후에 유면이 낮아지면서 $11 \mathrm{~mm}$ 의 해석 결과와 비교해보면 각각 $18,8 \mathrm{~Hz}$ 상승하였다. 그러 나 $487 \mathrm{~Hz}$ 는 $20 \mathrm{~Hz}$ 가 감소하였는데, 이러한 현상은 Fig. 5에서 나타낸 X, Y, Z 방향의 단순 공동에 대한 공진주파수 계산식, 식 (2), (3)에서 알 수 있듯이 각 방향의 길이에 반비례하기 때문이다. 즉 기동 후 유 면의 높이가 낮아져 압축기의 $\mathrm{Z}$ 방향 길이가 증가되 면 공진주파수는 저주파 영역으로 이동된다(3). 


$$
f=\frac{c}{2 \ell}
$$

여기서

$c$ : Speed of sound $(\mathrm{m} / \mathrm{s})$

$\ell$ : Length (m)

$$
c=c_{o} \sqrt{1+\frac{t}{273}}
$$

여기서

$c_{o}:$ Initial speed of sound $(\mathrm{m} / \mathrm{s})$

$t$ : Temperature $\left({ }^{\circ} \mathrm{C}\right)$

유면 높이의 변화에 따른 해석 결과에서 잔존 유 량이 $13 \mathrm{~mm}$ 일 때의 공진주파수가 실험결과와 가장 유사하게 나타났으며, Fig. 4에 나타낸 공동의 모드 형상을 살펴보면 $\mathrm{X}, \mathrm{Y}, \mathrm{Z}$ 방향의 공진주파수는 각 각 $522,446,473 \mathrm{~Hz}$ 이다. 따라서 실험과 가장 유 사한 조건인 잔존 유량 $13 \mathrm{~mm}$ 의 유한요소 모델을 기준으로 잔존 오일 유량, 냉매의 흡입위치 그리고 구동부의 위치에 따른 음향해석을 수행하였다.

\section{4. 압축기 내압의 주파수응답 특성 분석}

압축기의 운전조건 설정 및 설계에 활용할 수 있 는 이상적인 조건을 구하기 위하여 압축기의 운전 조건 및 구동부 위치에 따른 내압에 대한 공진점 주변에서 주파수응답의 피크 높이, 주파수 폭의 변 화, 주파수 이동 특성을 음향해석을 통하여 분석하 였다. 4가지 조건 즉 잔존 오일 유량, 냉매의 흡입 위치 그리고 구동부 위치변화에 따른 주파수응답의 변화 특성을 분석하였다. 주파수응답함수는 관심주 파수 범위 $(420 \sim 560 \mathrm{~Hz})$ 에서 냉매의 흡입구(가진부) 의 입구단에 단위속도 $(1 \mathrm{~m} / \mathrm{s})$ 의 진폭을 갖는 조화가 진에 의한 조화응답해석을 통하여 계산하였다.

Fig. 6은 잔존 유량조건에 따른 $\mathrm{X}, \mathrm{Y}, \mathrm{Z}$ 방향에 서의 주파수응답함수를 나타낸 것이다. 음향 모드해 석에서 얻어진 $\mathrm{X}, \mathrm{Y}, \mathrm{Z}$ 방향의 1 차 모드 공진주파 수에서 주파수응답함수의 피크가 나타남을 알 수 있다. 잔존 유량변화에 따른 공진 피크의 크기는 $\mathrm{X}$, $\mathrm{Y}, \mathrm{Z}$ 방향 모두 $16 \mathrm{~mm}$ 의 유면 높이의 조건이 상
대적으로 가장 낮고 안정적인 것으로 나타났다. 또 한 잔존 유량의 변화에 따라 공진주파수의 이동 현 상이 발생하였다. 주파수의 이동은 $\mathrm{X}, \mathrm{Y}$ 방향의 공 진주파수는 고주파 영역으로 약 $10 \sim 20 \mathrm{~Hz}$ 가 이동되 었으며, $\mathrm{Z}$ 방향의 공진주파수는 저주파영역으로 약 $20 \mathrm{~Hz}$ 의 이동현상이 나타났다. 따라서 압축기가 기 동하고 있을 때 잔존하는 유량의 높이 선정은 단지 주파수응답의 피크가 낮다고 해서 해결되는 것이

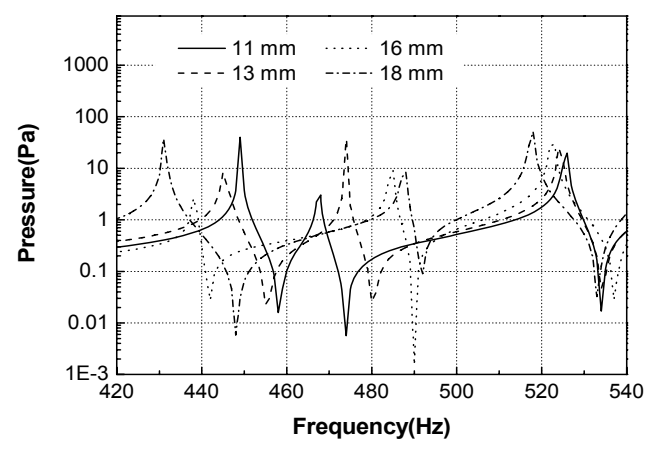

(a) X-direction

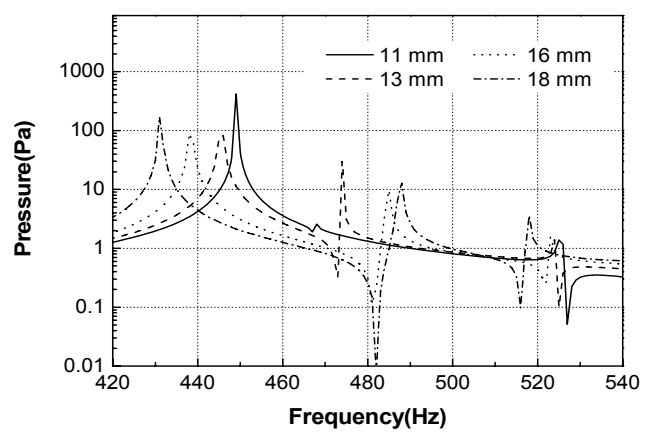

(b) Y-direction

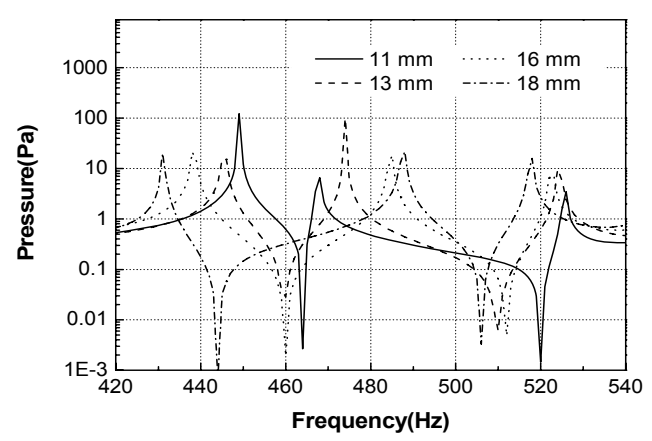

(c) Z-direction

Fig. 6 Frequency response functions for different heights of remained oil 
아니라 가진주파수와 공진주파수가 일치되지 않는 조건을 구하는 것이 매우 중요하다.

Fig. 7은 흡입관과 충전관으로 각각 냉매를 흡입 한 경우와 Fig. 2에서 X 방향 모드의 노달 라인 상 에서 한 점(nodal point 1)과 $\mathrm{X}, \mathrm{Y}$ 방향 모드의 노 달 라인이 교차되는 점(nodal point 2)으로 냉매의 흡입위치를 변경한 경우의 주파수응답함수이다. 충 전관으로 냉매를 흡입한 경우가 공진주파수 주변에

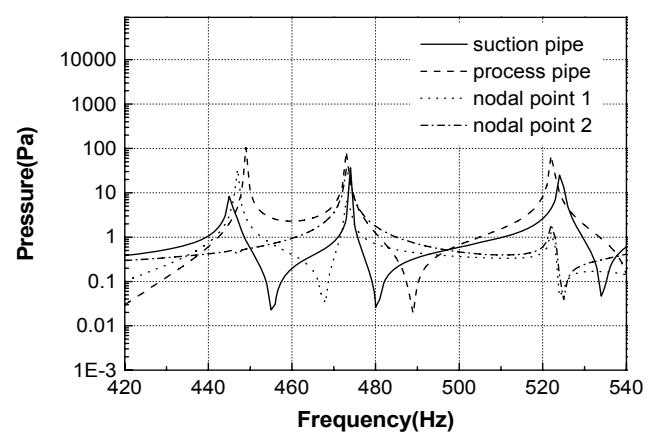

(a) X-direction

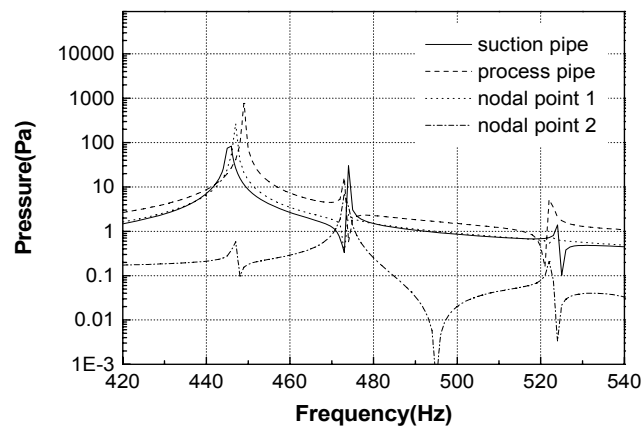

(b) Y-direction

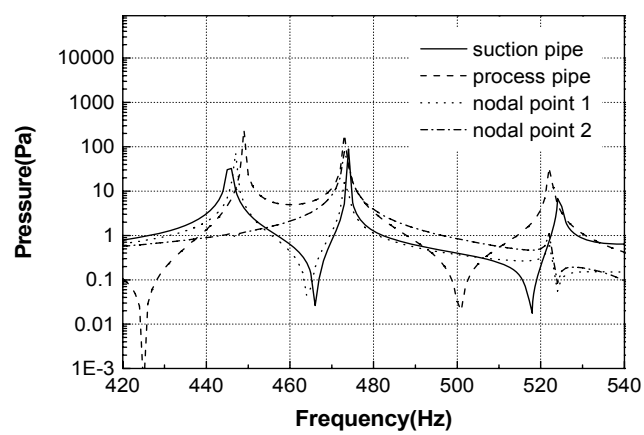

(c) Z-direction

Fig. 7 Frequency response functions for different excitation positions
서 상대적으로 피크가 높고, 주파수 폭도 넓게 발생 하였다. 그리고 각 조건에 따른 공진주파수의 이동 은 약 $2 \sim 3 \mathrm{~Hz}$ 정도로 작은 이동을 나타내었다. 따 라서 충전관을 냉매 흡입부로 대체하는 경우는 소 음저감에 불리한 것으로 판단된다.

노달 점 1 로 냉매의 흡입 위치를 변경한 경우는 $\mathrm{X}$ 방향 모드의 공진 피크가 크게 저감되었고, 노달 점 2로 냉매의 흡입 위치를 변경한 경우는 $\mathrm{X}, \mathrm{Y}$

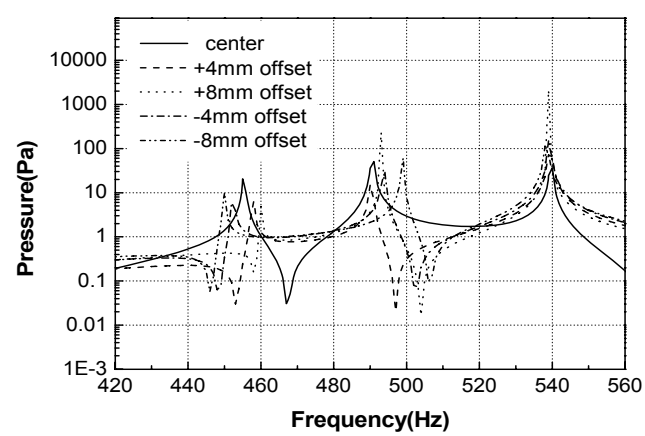

(a) X-direction

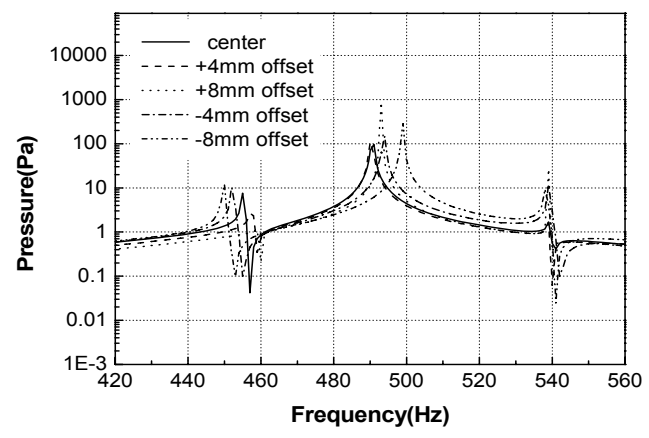

(b) Y-direction

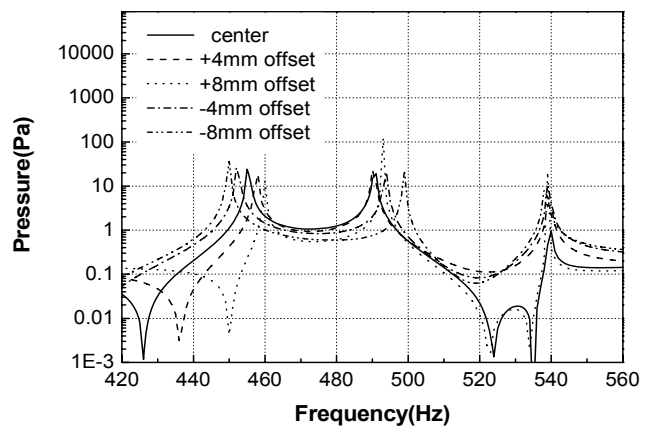

(c) Z-direction

Fig. 8 Frequency response functions for different positions of driving part 
방향 모드의 공진 피크가 동시에 저감되었다.

Fig. 8은 구동부의 위치 변경에 따른 주파수응답 함수를 나타낸 것이며, $\pm 4 \mathrm{~mm}$ 일 때 주파수의 크기 와 폭은 동일하고, 공진주파수의 변화는 $\mathrm{Y}, \mathrm{Z}$ 방향 의 모드에서만 발생하였다. 여기서 주파수 변화 폭 은 약 $3 \sim 5 \mathrm{~Hz}$ 정도이다. 구동부를 $\pm 8 \mathrm{~mm}$ 이동시킨 경우, 특히 $+8 \mathrm{~mm}$ 조건에서는 $\mathrm{X}, \mathrm{Z}$ 방향의 공진 피크가 크게 발생하므로 소음에 나쁜 영향을 미치 는 것으로 나타났다. 따라서 압축기 구동부의 위치 선정 시에는 압축기 공동의 중앙에 위치하는 것이 가장 이상적이며, 내부 부품들이 외부 셸에 가까이 갈수록 소음에 나쁜 영향을 미치는 것을 알 수 있 었다.

이상의 음향해석 결과에서 잔존 오일 유량을 16 $\mathrm{mm}$ 로 유지하였을 경우, 냉매의 흡입위치는 각 방 향의 노달 라인이 교차되는 위치로 변경하였을 경 우 그리고 구동부는 공동의 중앙에 위치하는 경우 에 소음저감 측면에서 가장 유리한 압축기 조건임 을 확인하였다. 압축기 설계 시 위의 사항을 고려하 여 조건설정이 이루어진다면 내부 공동의 공진에 의한 소음증폭을 방지할 수 있을 것이다.

\section{5. 결 론}

저소음형 압축기를 위한 운전조건 설정 및 설계 지침을 도출하기 위하여 음향해석을 통한 압축기의 운전조건 및 구동부 위치에 따른 공동 공진주파수 의 특성을 분석하였으며, 주요 연구 결과를 정리하 면 다음과 같다.

운전조건과 관련하여 잔존 오일 유량의 변화에 따 른 특성 분석에 있어서는 잔존 유량 높이가 $16 \mathrm{~mm}$ 일 때가 소음저감에 가장 유리한 특성을 보였다. 냉 매의 흡입위치에 따른 주파수응답의 특성 분석에 있어서는 모드해석에서 확인된 노달 라인의 교차점 에 흡입구가 위치했을 때가 소음저감에 가장 유리 한 조건임을 확인하였다. 그리고 구동부 위치에 따 른 공진주파수 특성 분석에 있어서는 구동부가 공 동의 중앙에 위치했을 때가 소음저감에 유리한 조 건임을 확인하였다. 따라서 음향해석을 통하여 도출 된 운전조건 및 설계방향은 저소음형 왕복동식 압 축기 설계에 유용하게 활용할 수 있을 것으로 기대 된다.

\section{참 고 문 헌}

(1) Kim, J. H., 1998, "Review of Noise and Vibration Research of the Hermetic Compressor,' Proceedings of the Korean Society for Noise and Vibration Engineering Conference, pp. 17 24.

(2) Johnson, C. N. and Hamilton, J. F., 1972, "Cavity Resonance in Fractional HP Refrigerant Compressors," Proceedings of the 1972 Purdue Compressor Technology Conference, pp. 83 89.

(3) Albrizio, F., Genoni, C., Bianchi, V. and Frontini, G., 1990, "Noise Reduction of Hermetic Compressor by Identification of the Gas Cavity Resonance," Proceedings of the 1990 Purdue Compressor Technology Conference, pp. 612 624.

(4) Akella, S., Venkateswarlu K. and Sundaresan S. A., 1992, "Cavity Resonances in Hermetic Compressors : a Finite Element Approach," Proceedings of the 1992 Purdue Compressor Technology Conference, pp. 1477 1486.

(5) Yoshimura, T., Akash, H., Inagaki, K., Kita, I., Yabiki, J. and Fujiwara, N., 1994, "Noise Reduction of Hermetic Reciprocating Compressor," Proceedings of the 1994 Purdue Compressor Technology Conference, pp. 253 258.

(6) Elson, J. P., 1978, "Vibration Related Testing for Hermetic Compressor Development," Proceedings of the 1978 Purdue Compressor Technology Conference, pp. 50 54.

(7) Brown, M. E., 1992, "Noise Identification and Reduction in Small Hermetic Reciprocation Compressors," Proceedings of the 1992 Purdue Compressor Technology Conference, pp. 331 339.

(8) SYSNOISE Rev 5.5 User's Manual, LMS International.

(9) Suh, K. H., Lee, H. and Oh, W. S., 1998, "An Analysis of the Hermetic Reciprocating Compressor Acoustic System," Proceedings of the 1998 Purdue Compressor Technology Conference, pp. 361 366. 